\title{
Thermal, chemical and bio-chemical interventions for enhancing the shelf-life of sugarcane juice
}

\author{
- DILIP KUMAR* AND PRIYANKA SINGH
}

ICAR-Indian Institute of Sugarcane Research, Dilkusha, LUCKNOW (U.P.) INDIA

Email : dilipiisr@gmail.com

\section{SUMMARY :}

Sugarcane juice is a popular drink in India, but in most cases it is unavailable in hygienic condition and due to its poor shelf-life it is often sold fresh. It deteriorates very rapidly due to physical, chemical and microbial changes. Attempts were made to preserve sugarcane juice by combining the effects of pasteurization, preservatives and enzymes. Sugarcane juice was pasteurized at $85^{\circ} \mathrm{C}$ for 10 minutes followed by addition of fresh lemon juice to maintain its $\mathrm{pH}$ at 4.2 and was immediately bottled. Ascorbic acid (40 ppm), potassium sorbate (120 ppm) and sodium benzoate (120 ppm) were added as chemical preservatives. Cinnamon oil was used as bio preservative and pectinase enzyme as enzymatic treatment. The juices were bottled and pasteurized in hot water at $85^{\circ} \mathrm{C}$ for 10 minutes and stored under ambient and refrigerated conditions. Physico-chemical (pH, T.S.S, browning index), microbiological (total plate counts, yeast and mould growth) and sensory (overall acceptability) observations were recorded. Chemical preservatives enhanced the shelf-life for upto 40and 60 days at ambient and refrigerated conditions, respectively. However, thermally treated juice also showed acceptable sensory and microbial properties upto 20 days of storage at ambient conditions and 60 days under refrigerated condition.

KEY WORDS : Sugarcane juice, Heat treatment, Storage, Sensory evaluation, Shelf-life

How to cite this paper : Kumar, Dilip and Singh, Priyanka (2017). Thermal, chemical and bio-chemical interventions for enhancing the shelf-life of sugarcane juice. Internat. J. Proc. \& Post Harvest Technol., 8 (2) : 69-74. DOI: 10.15740/HAS/IJPPHT/8.2/69-74. 